DOI: 10.2478/linpo-2013-0020

\title{
SANSKRIT AND PĀLI INFLUENCE ON LANGUAGES AND LITERATURES OF ANCIENT JAVA AND BURMA
}

\author{
BORIS ZAKHARYIN
}

\begin{abstract}
Boris Zakharyin. Sanskrit and Pāli Influence on Languages and Literatures of Ancient Java and Burma. Lingua Posnaniensis, vol. LV (2)/2013. The Poznan Society for the Advancement of the Arts and Sciences. PL ISSN 0079-4740, ISBN 978-83-7654-274-4, pp. 151-158.

This paper describes the linguistic and cultural influence of India on the countries of Indo-China in the 5 th to 15 th centuries AD. It is shown that India's penetration into South-East Asia took the forms of Late Brahmanism $\sim$ Early Hinduism and of Buddhism. Indian settlers were promoting different variants of Sanskrit written culture in Java. Differences between culturally dominant Sanskrit, the language of the Indian migrants, and the orally used Austronesian languages of Java were great; as a result of interaction between the two there appeared highly Sanskritized versions of Old Western Javanese (Kavi) and later also of Old Balinese. Between the 7th and 15th centuries a great number of literary texts in Kavi were created in Java.

The influx of Indian culture into ancient Burma, realized mostly by the land-route and only partially by sea, implied two main waves differing linguistically: the Sanskrit-bound wave and the Pāli-bound one. Under the influence of Sanskrit and numerous texts in Sanskrit a Mon script based on the Indian brāhmī was developed in Upper Burma in the 9th century; later on it became the national system of writing, in use even today. The starting point for the history of Pāli epigraphy and literature in Burma was $1058 \mathrm{AD}$ when Theravāda Buddhism was proclaimed the state religion of the Pagan kingdom. In the 11th to 15th centuries a great number of works in different fields of knowledge appeared in Burma. The language used in them was a creolized Pâli/Burmese resulting from the intensive linguistic interaction between Pâli and Sanskrit on one hand and the vernaculars on the other. The most important stages in the development of this language and of literary activity in it are characterized.
\end{abstract}

KEY WORDS: Java, Burma, language contact, creolization, cultural influence, literary processes

Boris Zakharyin, Department of Indian Philology, Institute of Asian and African Studies, Moscow State University, zakharyin@iaas.msu.ru

The territory of South-Eastern Asia in ancient times was inhabited by different tribes linguistically belonging to Austric language stock, represented by two branches: the AustroAsiatic and the Austronesian macro-families. For this period of time, evidence of the existence in "Nusantara" (as was the traditional name for the territories of Malaya, the Indonesian archipelago, and the Philippines) of any types of script or of written forms of culture are absent. Thus, the primary phase of epigraphical activity in Nusantara in reality coincides with the much later time of the 1st millennium $\mathrm{AD}$, when an early tribal aristocracy formed in ancient Sumatra and Java and the first states appeared there. The epoch was also marked 
by waves of the intensive linguo-cultural influence of Classical India on the newly-born countries of Indo-China.

India's penetration into South-East Asia involved two main routes - by land and by sea - and almost from the very beginning it took two forms: Late Brahmanism Early Hinduism at the beginning and Buddhism a little later. The bearers of the "imported" new faiths in Nusantara seem to have been Indian merchants, followers of Shaiva cults on one hand, and of Mahayana Buddhism on the other. They were using the sea-route: Vessels with merchants and their goods, having started from ports in Eastern and Southern India, were crossing the Bay of Bengal and coming to Sumatra and Western Java. For preaching, they and their South-East Asian followers were using the Sanskrit language as a cultural vehicle, and probably due to that, the coexistence of the two religions in Nusantara was quite peaceful. After the merchants, other representatives of Indian high strata also started coming to Nusantara: Brāhmanasas and Buddhist monks were serving as priests and counselors in royal courts of South-Asian countries; they were the preservers and promoters of different variants of Sanskrit written culture - from treatises on religion, philosophy, literature, or law to works on grammar, lexicography, and poetics. As a reminder of those events, engravings on stone plates in Sanskrit were created in Java. The earliest of them is supposed to have belonged to the time of the Javanese king Pūrnavarman of the 5th century AD. Plates with Sanskrit engravings were found also in Sumatra, where in the 7th to 10th centuries there existed the large Buddhist kingdom of the Shrivijaya dynasty. Numerous inscriptions of later epochs in Sanskrit and in local languages have also been discovered in the neighboring countries of ancient Indo-China - such as Burma, Thailand, and Malaya. Their distribution and amount (a few hundred pieces in total) clearly demonstrate that South-East Asia might have been a citadel of Indian culture since at least the 2 nd century BC, or even earlier.

No systems might be structurally more different than those of the two languages in contact: the isolating and analytical Old Javanese and the inflectional and synthetic Sanskrit. The phonological system of Old Javanese may be looked at as a reduced version of that of Sanskrit: 6 vowels plus 20 consonants in the former and 14 vowels and 36 consonants in the latter. The qualitative differences were also significant, as opposition in length was relevant for a considerable number of vowels in Sanskrit while for the Javanese vocalic system it was completely irrelevant. There also existed considerable differences in consonantal subsystems. For example, each of the 5 series of Sanskrit occlusives (guttural - palatal - retroflex - dental - labial) was organized on the basis of three phonological oppositions: 'nasal $\leftrightarrow$ non-nasal', 'voiced $\leftrightarrow$ non-voiced', 'aspirated $\leftrightarrow$ non-aspirated'. Though Old Javanese was formally characterized by the same number of consonantal series, among the relevant oppositions for lexical units of Javanese proper the series of aspiration was absent. As for 'voiced $\leftrightarrow$ non-voiced', it seems that originally this opposition was also absent from the consonantal subsystem, and its place was occupied by the opposition 'tense $\leftrightarrow$ nontense'. Only later, after penetration of numerous Sanskrit borrowings into the language, the consonantal system of Old Javanese got restructured and became partially similar to that of Sanskrit.

The two languages also differed considerably on the level of phonological syntagmatics as consonant clusters were normal in Sanskrit, but were not allowed in Javanese. The structure of word-forms was simple in Old Javanese in comparison with the rather complicated 
one of Sanskrit: Many word-forms of Old Javanese were pure roots devoid of any affixes, while in Sanskrit unaffixed words could not be used in a sentence. In addition to affixation (which was less developed in Old Javanese than in Sanskrit) both languages had recourse to reduplication, but its role was different: While in Javanese, reduplication (complete or partial) was the very core of the system, in Sanskrit grammar its place was rather a peripheral one.

While Sanskrit possessed a highly developed set of morphologically expressed grammatical categories, there were only few of them in Old Javanese. For example, such significant Sanskrit categories as Gender, Number, Person, Case, Tense were absent from Old Javanese. Consequently, the role of such types of grammatical relation as government and agreement was highly important for Sanskrit, but, contrastively, irrelevant for Old Javanese, where the order of constituents and the usage of auxiliaries were the main syntactic devices.

Thus, the general incompatibility of the two languages seems to have been quite evident. Still, as a result of interaction between culturally dominant Sanskrit and the orally used Austronesian languages of ancient Java there appeared highly Sanskritized versions of Old Western Javanese (Kavi) and later also of Old Balinese.

One of the most ancient engravings in Kavi, created under the rulers of Shrivijaya or Shailendra dynasties, dates, probably, to the year 732 AD. During the period between the 7 th and 9th centuries literary texts in Kavi started regularly appearing in Java. Right from the start they were almost exclusively poetic. One of the earliest was a poem, Chandakarana, which described norms of Sanskrit prosody and metrics and was approximately written in 768. The poetic style tembang gede, presented in Chandakarana, presupposed a rather good knowledge of Sanskrit grammar and lexical units: thus, the text might be understood and implemented into practice only by well educated local aristocrats. Members of lower strata of the society must have been practicing the other poetic style, the one called kidung, which later came to serve as a basis for purely Javanese poetry.

The second part of the century was marked by the appearance of the first Sanskrit - Kavi dictionaries and of rather primitive grammars. They were written in the so called Early Pallava script, one that was similar to the grantha of Southern India, and grantha in its turn may be looked at as a modification of the traditional Indian brāhmī. In the 10th century the same Early Pallava script was used for writing down the Javanese Ramayana, and still later on its basis was created the local charakan alphabet, which lasted in Java till the 17th century, when it was ousted by Roman script. Though differences in vowel length and consonant aspiration were in general foreign to Austronesian languages, due to the extreme infiltration of Sanskrit words into Old Javanese texts (up to 30-40\% of the lexicon), separate symbols for long vowels and for aspirated consonants were introduced into charakan.

One of the earliest prose texts of ancient Java is considered to have been the philosophical treatise on Tantric Buddhism Sang hyang kamahayanikan. It was created approximately in the 8th to 9th centuries on the island of Bali, and its medium of expression was generally Old Balinese, though a lot of special terms and expressions were borrowed directly from Sanskrit. The main theme of the treatise was the description of the quickest ways of final emancipation from matter and attaining the Supreme Bliss (nirvāna). Probably at the same time or slightly later, in Central Java appeared another Tantric treatise, the Bhuvanakośa, dedicated to Shaiva mythology and philosophy. The text was presented in the form of a dia- 
logue between god Shiva and one of his adepts desirous to understand the necessity and ways of attainment of final reunion with the Absolute by the individual Self.

The period of the 9th-11th centuries was characterized by intensive assimilation of the Indian cultural heritage by Javanese poets. The Indian poetic masterpieces, translated or transposed from Sanskrit into Kavi, started appearing in plenty. "Javanization" of the original plot, heroes, and time and place of action was most typical for literary production of this kind, only the degree of "Javanization" was different for different kinds of works. As a good example serves the Javanese Brahmāndapurāna, in which all the important events are associated not with India, but only with Java into which even the centre of the Universe is shifted: The place and functions of the Indian Meru-parvata are instead attributed to one of the mountains in Java. The most important works of the described sphere of literary activity were translations/transpositions of the two Indian epic poems, the Mahäbhärata and Rāmāyana. A prose transposition into Kavi of approximately half of the Indian Sanskrit Mahābhärata was completed by the end of the 10th century in Eastern Java. In the course of this transposition the contents of the Sanskrit treatise were changed: Many of the so-called interpolated stories, not connected directly with the main topic, were omitted and a lot of insertions, significant for Javanese aristocracy, were made. At approximately the same time, two other important transpositions in Kavi appeared: the prose version of the last (7th) book of Sanskrit Rāmāyana and the Buddhist text Kumjarakarna.

The source for the mentioned portion of the Ramanyana seems not to have been the canonical Rāmāyaṇa of Vālmīki, but some other text, probably belonging to the oral tradition of India. Even less information is available concerning the origin of Kumjarakarna. The ideological background of this prose story were the tenets of Mahayana Buddhism, and the plot was focused on the figure of the rākșasa Kumjarakarna (literally 'one having elephantlike ears'). The story describes how Buddha Vairochana, who according to Buddhist mythology is guarding the Southern regions of the universe and consequently is considered to be a kind of a "sky-patron" by all the Buddhists in Java, managed to completely transform the conscience of Kumjarakarna, so that the latter, having given up his rākșasa nature, became a true follower of the Buddhist path.

One of the most interesting samples of Indian literature in ancient Java was the poetic text of the Javanese Rāmāyana, which appeared in Central Java in approximately the very beginning of the 10th century; its author is unknown. The work was a transposition of the famous Bhattikāvya created in Sanskrit by the distinguished Indian scholar and poet Bhatți Svāmin at the end of the 6th or the beginning of the 7th century (a more exact date cannot be established at present). According to some Indian legends, the Bhattikikavya (another title was Rāvana-vadha) had originally been planned by its author as a poetic description of the life and heroic deeds of Rama, but later on Bhatti changed his intensions and decided to write a poem that would be Rama's story, on one hand, and serve as illustrations to grammatical rules of Pānini's Aștāadhyāyl on the other. The author of the Javanese Rāmāyana was not very strict in following the original Sanskrit poem and concentrated more on Rama's "biography", inserting a lot of his own interpolations into the text. The grammatical constituent of the poem was also not completely forgotten, but in parts dedicated to metrics and rhetoric. The author preferred to introduce stanzas corresponding to local traditions of versification and to discuss the Sanskrit poetic norms only in passing. From the very beginning the $J a$ - 
vanese Rāmāyana became a model for native poets, and in the 13th to14th centuries and later there started to appear many imitations of the text, especially in Eastern Java. It should be stressed that for the pseudo-epic poetic works in Kavi their Indian Sanskrit prototypes served only as a kind of superficial "shell" under the cover of which, at a deeper level, practically everything was of Javanese origin - the events, the heroes, the landscapes, the animals, birds, or plants described, etc.

While in Java the spread of Indian culture was indebted exclusively to the sea-route, the influence of Indian culture on ancient Burma was brought about mostly by land-route and only partially by sea. There were at least two main waves of Indian cultural penetration into Burma, and they differed linguistically.

The first, Sanskrit-bound wave seems to have reached Burma in the last centuries BC. Its starting point was Eastern India - through the Manipur mountains to Upper Burma, and through Arakan into Lower Burma. It is stated in the Burmese chronicles that this Indian expansion into Burma had started a few centuries before the time when the Buddhist religion got itself rooted in Eastern India and Burma and that it happened under Shakya rulers who came to Upper Burma from Kapilavastu. There are no trustable testimonies to this, as the earliest Burmese inscriptions in Pāli mentioning this claim go back only to the 5th century AD.

Still, there cannot be any doubts that the acquaintance of the Burmese people with Sanskrit works must have taken place in epochs much earlier than the appearance of Buddhist Theravāda doctrine and texts in Pāli on the territory of the country. The exact time cannot be established with certainty, but probably it was during the early centuries AD, when Upper Burma was inhabited by Mon, Pyu, and some other bellicose tribes who were speaking different Sino-Tibetan languages. The influx into this area of Sanskrit, mainly religious texts from India had serious consequences, as there appeared a Mon script based on one of the Eastern variants of $b r \bar{a} h m \bar{\imath}$. In the 9th century AD the Burmese proper, speakers of LoloBurman languages, invaded these territories from the North. After a long period of wars between the newcomers and the aborigines, the latter were defeated and by the end of the 10th century the state of Pagan was founded. The ethnically dominating Burmese then borrowed from Mon their script and after making some amendments, transformed it into the native system of writing that is in use in Burma even today.

The penetration of Indian culture into Lower Burma seems to have taken place earlier - probably in the 5th century when Buddhist religious ideas and texts started coming into this region from India and Sri Lanka. At first these must have been Theravāda treatises in Pāli - quotations from them are present in 5th century gold-plate inscriptions from Maunggun. Later on, starting from the 7th century, there also appeared texts in Sanskrit, expounding the fundamental tenets of the Mülasarvāstivādī sect of Buddhism.

In the year of 1058 king Anoratha of Pagan proclaimed Theravāda Buddhism the state religion. Under his patronage tight religious contacts were established with Sri Lanka and Southern and Eastern India which since long had been considered the strongholds of Theravāda and its canon in Pāli (the latter was called māgadhabhāsā 'the language of Magadha' in Burma). This was the starting point for the history of Pāli epigraphy and literature in Burma. One of the oldest inscriptions in Pāli made in Burmese script was the 1058 engraving on stone telling about king Anoratha's conversion to Buddhism and about his triumphant campaign against the neighboring Thaton, from where the Tipitaka and other 
sacred manuscripts in Pāli had been brought to Pagan. The Tipitaka was probably one of the first texts in Pāli to be read and attentively studied by literate Burmese. After it, a great number of Pāli works on religion, philosophy, grammar, metric, law, etc. followed, and in the period between the 11th and 14th centuries their inflow was constantly progressing. Very soon Burmese scholars started to write in Pāli their own commentaries on Buddhism treatises, first of all on the Tipitaka. For example, already in the 14th century there appeared a commentary on the Vinaya Pitaka by Chapata called Vinayagū also the author of Kaccāyanasuttaniddesa, a Burmese version of the famous Pāli grammar by Katyāyana. Later, in the 15th century, Ariyavamsa, a follower of Chapata, created Jātakavisodhana, a commentary on Jātaka stories of the Sutta Pițaka. He also has the work Abhidhammatthabhāvanī to his credit, a commentary on the Abhidhamma Pitaka.

Grammatical and metrical studies also were not forgotten: Already in 1154 Aggavamsa wrote a grammar of the Tipitaka language called Saddaniti, and some years later another grammatical work was issued by him - the Dhätumāla , in which he tried to provide correspondences between Pāli and Sanskrit. Saddhammañāṇa wrote a number of works dedicated to Pāli and Burmese metre and prosody; he is also reported to have translated the Sanskrit Kātantra Vyākaraṇa into Pāli.

It should be stressed that though Pāli was treated as the most important language of culture, Sanskrit was considered a very prestigious language also. In the days of king Anoratha and later it remained a highly honored means of expression, and many counselors of Indian origin, well taught in Vedic and Sanskrit literature, were on service at the royal courts of Burma. The Kalyāñ inscription of 1442 mentions a number of Sanskrit works that were in great esteem among the Burmese - among them were the Kätantra and Kāśikā grammars, Amaru's dictionary, treatises on Ayurveda, etc.

Under the impact of Pāli and Sanskrit on the vernaculars the literary Burmese evolved in the 14th century. The majority of specimens in early Burmese were in prose, dedicated mostly to religious and philosophical problems, but only the titles are known to us, as original works anterior to the 15 th century have perished. The only poetic composition that has reached us from the time of the Pagan kingdom is the famous Dhammatadi, which is considered to be a masterpiece of Burmese poetry. Since the second half of the 15 th century literary Burmese has become a regular language of culture in Burma.

The Old Burmese language structure differed greatly from that of Pāli or Sanskrit, and the differences extended to practically all linguistic levels - phonology, morphology, wordformation, syntax, and semantics. Old Burmese was an isolating and analytical, predominantly monosyllabic language with tones and a simple system of phonemes the distribution rules of which implied strong limitations in syllable-final position. Grammatical relations were expressed through order of the constituents or with the help of auxiliaries. Contrary to Old Burmese, Sanskrit and Pāli, as has already been remarked, were inflectional and synthetic languages with a high degree of morpheme fusion within word-forms and a large number of nominal and verbal categories expressed by morphological devices. But, as it earlier happened in Java, the situation of constant and intensive cultural interaction in ancient Burma almost automatically led to the creation of a creolized Pāli/Burmese language, different varieties of which were used by native authors in works of religion, philosophy and arts.

The main peculiarities of Pāli/Burmese involve the following phenomena: The system 
of script fully imitates the Indian alphabets, with 8 symbols for vocalic phonemes, 32 for consonantal, and 1 for the phoneme of nasalization $(\dot{m})$. The phonological system of Burmese proper was simpler. Moreover, the contrast of consonants in Burmese had originally been based on the opposition 'tense - non-tense' and not on the opposition of length, as it was in Pāli. This might have been the cause of errors in the graphical forms of words in Pāli /Burmese - see e.g. variations like chada- chäda- chadda- 'cover; veil'. The consonantal opposition 'retroflex - non-retroflex' also originally did not exist in Burmese - thus, dental and retroflex consonants might be intermixed in texts, as in tuttha- (= Pāli tuttha-) 'satisfied', but jațaka- (= Pāli jātaka-) 'a story about Buddha's rebirths'. As grammatical gender was absent from the nominal system of Burmese, gender markers in Pāli/Burmese might

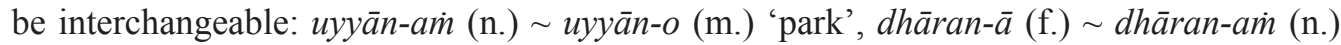
'memory'. The cases also might be used wrongly - e.g., in place of the ablative in samudd- $\bar{a}$ uttaritva 'having come out from the sea' we find the accusative, samudd-am uttaritva , literally 'having come out into the sea'. While in Burmese there were only two tenses: present/ past and future, forms of present and past (preterit) were well differentiated in Pāli - thus, there were cases in Pāli /Burmese when the form of the present tense was wrongly used in the place of the past.

Differences like those described, however, were not insuperable obstacles: The mutual adjustment of the two languages and constant interaction between them were favoring the creation and later flourishing of the creolized Pāli/Burmese in non-canonical texts. As for treatises of the Buddhist canon and commentaries on them in Pāli, however, Burmese scholars and monks had demonstrated great mastership in using the language already in the 15 th century, and those skills were carried on by them through later epochs also.

\section{REFERENCES}

Aung S.Z., Rhys Davids C.A.F. 1910. Compendium of Philosophy (Abhidhammattha-Saygaha). London: Pali Text Society (reprinted 1956).

BhattacharJeE Arun. 1981. Greater India. New Delhi: Munshiram Manoharlal.

Bode Mabel Haynes. 1908. "Early Pāli grammarians in Burma." Journal of the Pāli Text Society 62, 81-101.

Bode Mabel Haynes. 1909. The Pāli Literature of Burma. London: Royal Asiatic Society of Great Britain and Ireland.

Burling Robins. 1967. Proto Lolo-Burmese. Bloomington-The Hague: Indiana University Research Center in Anthropology, Folklore, and Linguistics/Mouton.

Coedes Georges. 1967. The Indianized states of South-East Asia. Honolulu: East-West Center Press.

DAhl Otto Christian. 1977. Proto-Austronesian. 2nd edition. (Scandinavian Institute of Asian Studies Monograph Series, 15.) Lund: Studentlitteratur.

Kulke Hermann. 2001. Kings and cults: State formation and legitimation in India and Southeast Asia. Reprint, New Delhi: Manohar.

LAw Bimala Chum. 1933. A history of Pāli literature. vol. I-II. London: Kegan Paul, Trench, Trubner \& Co. Repr. 2000, Varanasi: Indica.

Majumdar Ramesh Chandra. 1955. Ancient Indian colonisation in South East Asia. Baroda: Oriental Institute of Baroda.

PARnIKel' Boris B. 1980. Vvedenie v literaturnuju istoriju Nusantary IX-XIX vv. (Introduction to the history of Nusantara literature in the 9th-19th centuries). Moscow: Nauka.

PATNAIK Ashutosh Prasad. 2003. The Early Voyagers of the East. Vol. II. Delhi: Pratibha Prakashan.

Popov Genrix P. 1967. Birmanskaja literatura (Burmese literature). Moscow: Nauka. 
Sмiтн Helmer (ed.). 1949. Saddanīti: La grammaire pālie d'Aggavamsa. Part I. Lund: Gleerop.

TesëLKIN Avenir Stepanovič. 1963. Drevnejavanskij jazyk (kavi) (The Old Javanese Language (Kavi)). Moscow: Izdatelstvo Vostočnoj Literatury.

Warder Anthony Kennedy. 1963. Introduction to Pali. London: Pali Text Society.

Zoetmulder Petrus Josephus. 1974. Kalangwan: A Survey of Old Javanese Literature. The Hague: Nijhoff. 